\title{
Unemployment and the future
}

\section{Most Western governments are seeking separate solutions for unemployment. They should do more to prove to the jobless that there will be a future, and should agree how to bring it about.}

The long recession in the industrialized West has now brought its most daunting and predictable consequence: unemployment. In Britain, the total now out of work exceeds 3 million, or close on 10 per cent of the potential workforce. In West Germany, after several resilient years, the jobless rate is now pushing 7 per cent. In the United States, the growth of unemployment has been even sharper. Even Japan has not escaped unscathed. So it is inevitable. that there should be great cries of protest at this state of affairs, and that governments everywhere should be under pressure to modify their monetary policies, devised with varying degrees of good sense to counter rapid inflation. (Reagonomics, devised in Washington with the different objective of unshackling industrial production, has had the same effect because the hard-headed New York money markets have agreed to let the Administration and others borrow money only at deflationary interest rates.) Politically, such pressures cannot indefinitely be resisted. In Britain, it is well remembered that the Heath government embarked in 1973 on its ultimately disastrous policy of reflation because unemployment had exceeded the daunting figure of one million. Although all governments except the French say they will continue to regard unemployment as a kind of lesser evil, the danger is that they will hurriedly change course for the wrong reasons, and at the wrong time.

Unemployment at the rates now customary is naturally hard for even those still at work to stomach. For those without jobs, a large proportion of the younger of whom have never worked, unemployment is a personal tragedy that is only inadequately offset by programmes of social security devised to avoid the improverishment of the 1930 s. So much is commonly accepted, as is the proposition that a high degree of unemployment is a social waste of people's capacity and willingness to work. Yet the present plight of a substantial proportion of the working population in advanced societies is not merely an inevitable but an intended consequence of economic policies now in force, which have in turn been forced on governments by events in the past decade and in particular by the substantial increase of the international price of oil in 1973 and 1979. To pretend otherwise is to suppose that the rules of simple arithmetic can be suspended at will - which is not to say that there is nothing that can be done.

The first need, however, is to be clear where the present trouble has come from. Compared with the happy years before 1973, oil consumers are now paying more than $\$ 200$ extra for each tonne of oil they use. For many, this entails a straight transfer of resources to the oil-producing states, which may either decide to convert their funds into a claim on the resources of the oil consumers or, alternatively, may choose to lend back the money through the banking system. Either way, customers for oil on the international markets can have hoped to weather these storms without impoverishment only by increasing their production and therefore their productivity. Japan and West Germany honourably followed that principle for several years. Elsewhere, governments chose to follow their voters' wish that the truth should be concealed from them; inflation gathered pace and had then to be countered by deflationary policies which reduced people's capacity to buy what they think they need and which in turn have now cast their shadow on the economic stalwarts of the West. This argument applies even to Britain, outwardly selfsufficient in oil, because the once cheap oil from the Middle East has been replaced by expensive oil from the North Sea, won only by capital and resources that might otherwise be used for more productive purposes.

For those who would cure unemployment quickly, the snag is that increased productivity is the enemy of job creation. The dilemma for Western governments is that the continuation of the recession will improve the former - even in Britain, productivity in manufacturing industry increased by more than 7 per cent last year - but will increase the unemployment queues. And the opposite is true - reflation would reduce the immediate misery of unemployment but jeopardize the long-term health of the economy. So are governments irretrievably boxed in? Not necessarily. Those most seriously afflicted are right to resist demands that jobs should be "created" in uneconomic pursuits but, on recent form, cruelly indifferent to the need to explain how the unemployment problem may eventually be solved. People who have just lost their jobs are understandably unwilling to accept that their misfortune must wait while inflation is contained. So what should governments attempt to do?

First, domestically, there is an urgent need that people displaced from jobs that have disappeared should be given a tangible and imaginative opportunity to prepare for the more productive world in which they may yet have the good fortune to live. Although the British government, for example, now plans to spend more generously on training programmes, and is in particular planning to offer every school-leaver who fails to find a job some structured opportunity for training at work, there is nothing to suggest that the results will generally be to make people more employable in the years ahead. By the same tests, all governments must recognize that the key to long-term prosperity - production, productivity and employment all high - is a more effective international division of labour than at present. Here too, unfortunately, the omens are not cheerful. Protectionist tendencies are increasing, with governments seeking to shield from overseas competitors industries that will never make economic sense. Is there a chance that the folly of these policies will be openly acknowledged, as it should be, at the "economic summit" advertised for June?

While they are about it, the governments in June should tackle the still more tricky question of how collectively to manage the transition from where we are to where we hope to be. What criteria will be used for telling when it will again be safe to let up in the battle against inflation? By what common criteria should governments decide that the time has come to invest in public works, or to allow commercial companies to borrow money at more modest interest rates? And by what agreed rules should the value of national currencies be determined and then adjusted? Putting these questions to many of the more orthodox turning up in June will be a little like asking a gathering of churchmen to define the circumstances in which sin is acceptable. In reality, the challenge is not so great. For the agreements negotiated towards the end of the Second World War at Bretton Woods in the United States, which were the basis of international financial relations until they collapsed between 1969 and 1971, were themselves an awkward adjustment between financial probity and an imperfect world. What is needed now is an open recognition that the world is far from perfect, that the governments that inhabit it are even less so and that, nevertheless, they must agree to act in concert. 